\begin{abstract}
"Mircea cel Batran" Naval Academy Scientific Bulletin, Volume XIX - 2016 - Issue 1
Published by "Mircea cel Batran" Naval Academy Press, Constanta, Romania /I The journal is indexed in:

PROQUEST / DOAJ / DRJI / JOURNAL INDEX / I2OR / SCIENCE LIBRARY INDEX / Google Scholar / Crossref /

Academic Keys I ROAD Open Access / OAJI / Academic Resources / Scientific Indexing Services / SCIPIO
\end{abstract}

\title{
DATABASES ROLE CORRELATED WITH KNOWLEDGE TRANSFER BETWEEN ENTITIES OF A CLUSTER
}

\author{
Claudiu PIRNAU ${ }^{1}$ \\ Mihai Alexandru BOTEZATU2 \\ luliu Stefan GRIGORESCU ${ }^{3}$ \\ ${ }^{1}$ The University of South East Europe Lumina, Faculty of Information Technology, claudiu.pirnau@lumina.org \\ ${ }^{2}$ Romanian - American University, Faculty of Computer Science for Business \\ Management, mihaibotezatu@gmail.com \\ ${ }^{3}$ Academy of Economic Studies, Faculty of Accounting and Management Information \\ Systems, grigostfansdrconta@yahoo.com
}

\begin{abstract}
Knowledge transfer between organizations members of a regional cluster is influenced both by the complexity of the tasks, and the experience of user groups. The integration of knowledge (tacit, explicit and potential) in current activities of a trader involves the creation of an efficient use of specific databases. The issue of knowledge transfer can be analyzed from four perspectives: using cloud technologies (development of platforms for cloud applications is an important strategy, especially in activities within a geographically dispersed network); empowerment (granting freedom of each employee to contribute in the decision making process, in the power distribution according to his competence and in accordance with the objectives and culture of that organization); development and implementation of more efficient knowledge sharing procedures; analysis of the interdependence between quality and quantity of knowledge, its source and destination, such as modelling and simulation techniques, public administration management, knowledge management and that of management cooperation in strategic cluster alliances. The issue of knowledge sharing will be developed by means of a system based on an original interpretation of methods After Action Review and respectively SMART (Specific, Measurable, Assignable, Realistic, Time-related).
\end{abstract}

Keywords: cloud, databases, information, interdependence, knowledge transfer.

\section{INTRODUCTION}

In the new knowledge-based economy, particular attention should be paid to new knowledge storage in databases. This process leads not only to increased learning ability and innovation at individual and organizational level, but also increases productivity of databases, a phenomenon that will implicitly lead to organizational performance. The main processes of knowledge transfer analyzed in the specialized literature are socialization and association [1]. In this paper, we will consider mainly the transfer of knowledge to the cluster strategic alliances. Databases specific to clusters oriented towards regional development (Clusters Oriented regional database) not based on the classification of economic statistics, but regional value chains existing at K-regional SWOT analysis. So, there will be identified the best performing fields to be associated with future clusters: Specialized Automation (MAC), Plastics Industry (PLA), Biotechnology (BIO), Electronics \& Electrical Engineering (EE), Automotive Industry (AUT), Specialized Trade \& Logistics (LOG) etc [2].

In this context, adapting IT solutions did not fail to make itself present. An important example is the "NoSQL databases", an alternative to relational databases. NoSQL is not just SQL as it is not only a storage mechanism, being a hashtag (\#nosql) adapted to the new requirements for databases[3].

In recent years, the economic crisis effects has increased the number of clusters, the association being the only effective way to sustainable regional development. In this context, adapting IT solutions did not fail to make itself felt. An important example is the "NoSQL databases", an alternative to relational databases. NoSQL is not just SQL as not only a storage mechanism, being a hashtag (\#nosql) adapted to new requirements for databases. NoSQL main advantages are that it does not use the relational model, is effectively running on cluster structure, is based on many open-source applications with minimized structures specific to the new locations "real estate business". NoSQL allows users to develop databases without the need to convert in-memory structures to relational structures [4].

\section{AGGREGATE-ORIENTED DATABASES}

Web applications development within a platform is a vital factor in the data storage process, because in these situations arises the need to manage large volumes of data by running on clusters (based on using SQ) [24]. Relational databases were not designed to run efficiently on clusters, an example may be that of storage requirements of applications such as ERP, used in modern organizations, very different from those specific to 


\begin{abstract}
"Mircea cel Batran" Naval Academy Scientific Bulletin, Volume XIX - 2016 - Issue 1 Published by "Mircea cel Batran" Naval Academy Press, Constanta, Romania /I The journal is indexed in: PROQUEST / DOAJ / DRJI / JOURNAL INDEX / I2OR / SCIENCE LIBRARY INDEX / Google Scholar / Crossref / Academic Keys I ROAD Open Access / OAJI / Academic Resources / Scientific Indexing Services / SCIPIO
\end{abstract}

social trade based on social networks[5][18-20]. Aggregate Oriented Databases is a database collection on which NoSQL interacts, considering them as a single stand-alone entity. These units of data or aggregated define the procedures and limitations for complex operations with databases, values of primary keys and documents. Aggregation modality with a database is greatly simplified in clusters because the data unit may be located on any machine, computer or car, recovery of certain data being also accompanied by all related data. In this case it uses two styles of data sharing[7]:

- Sharing: different data sharing across multiple servers so that each server to act as a single source for a subset of data;

- Replication: replicating data copies across multiple servers, so that every bit of data should be found in several places. Replication is used in the following forms: master slave replication provides automatic replication of custom data types selected from one or more nodes (master) designated towards a single authorized node (slave), significantly reducing the chance of conflicts when upgrading; peerto-peer replication, used within very flexible architectures, may enable such replication of data copies on a portable computer.

Establishing the coordinates of basic network nodes allows synchronization of required data copies, avoiding overloading a single server. NoSQL databases are concentrated (specialized) in most cases on a single issue, such as scalability or use a particular data model. Main advantages of using NoSQL are[8][21-22]:

- Large volumes of rapidly changing structured, semi-structured, and unstructured data;

- Horizontal scalability;

- Agile sprints, quick schema iteration, and frequent code pushes;

- Avoiding unnecessary complexity;

- Object-oriented programming that is easy to use and flexible;

- Prevention of object-relational mapping;

- Geographically distributed scale-out architecture instead of expensive, monolithic architecture;

- High efficiency.

Considering that in the hypothetical cluster there is a manufacturer of plastic (PLA), which opens its production in all establishments of the car manufacture industry (AUT), regardless of the type of entity (business, auto service, auto parts store, etc.) and in companies specialized in logistics (LOG), use of NoSQL databases can be shown in Figure 1.
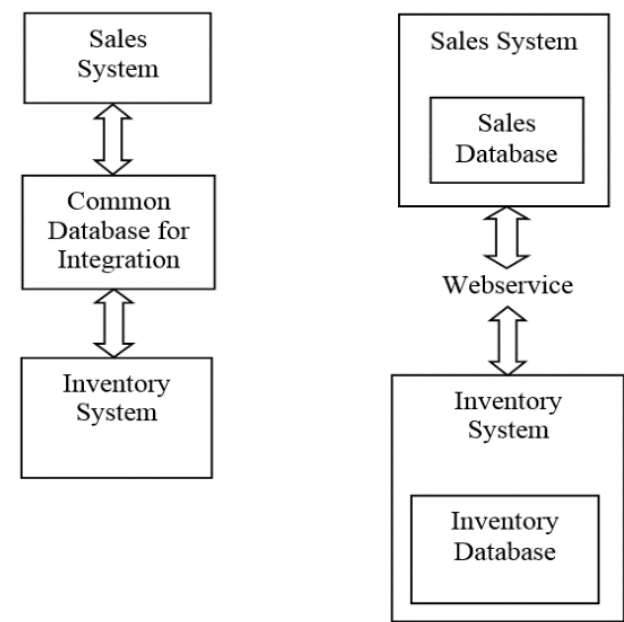

Fig. 1. NoSQL model data

NoSQL databases can be divided into four categories: Key-Value Stores, Column-based Stores (Example: electronic payments as shown in Figure 2), Document Stores (storing documents in accordance with a scheme) and Graph Databases, where the graph is a set of objects (nodes) and relations between them (edges)[9].

\begin{tabular}{|l|l|l|l|}
\hline ID: 1186 \\
\hline Customer: Claude \\
\hline Line Items: \\
\hline 0754892131 & 2 & $€ 51$ & $€ 99$ \\
\hline 0259455797 & 1 & $€ 65$ & $€ 65$ \\
\hline 0365974556 & 1 & $€ 71$ & $€ 71$ \\
\hline Payment Details \\
\hline Card: & \multicolumn{2}{|l|}{ Visa } \\
\hline CC Number: & 56789 \\
\hline Expiry: & $06 / 2018$ \\
\hline
\end{tabular}

Fig. 2. Structure of a column

Based on the philosophical-psychological work of the French scholar Henri Ey (1900-1977), can be defined that "being aware means to have a personal model of the world". So, the individual incorporates a model of the world that includes his own experiences he disposes of freely, as a person. In another scientific work the scholar considers consciousness "that form of basal activity of the brain and thinking that can be defined by the formation of perceptual or representative forms of already lived events" [10]. In the case of this scientific research "personal model of the world" is represented by the interactions between knowledge and different activities/entities existing within a cluster (model of regional cooperation).

Each person accumulates knowledge using the results or their interpretation within three 


\begin{abstract}
"Mircea cel Batran" Naval Academy Scientific Bulletin, Volume XIX - 2016 - Issue 1
Published by "Mircea cel Batran" Naval Academy Press, Constanta, Romania /I The journal is indexed in:

PROQUEST / DOAJ / DRJI / JOURNAL INDEX / I2OR / SCIENCE LIBRARY INDEX / Google Scholar / Crossref /

Academic Keys / ROAD Open Access / OAJI / Academic Resources / Scientific Indexing Services / SCIPIO
\end{abstract}

development processes: personal, organizational and regional.

Collection, use and sharing of knowledge is even more effective as the individual has a higher level of consciousness (personal and environmental). In the conditions of economic crisis, learning organizations are the only able to provide a high performance level.

Part of the knowledge gained are used to obtain information about their systems under development (inputs, outputs etc.) using simulation-modelling techniques[11].

Starting from the process of identifying the links between knowledge, awareness and techniques of simulation modelling ("experiences", "information" and "thinking" - synonymous with "Judgement"), in conjunction with the definition of knowledge as a combination of experiences, values, contextual information and intuition, and from the assumption that any logical thinking generates logical true knowledge, we can define a new element of the economy based on knowledge, namely "the circle of knowledge" (knowledge circle), shown in Figure 3.

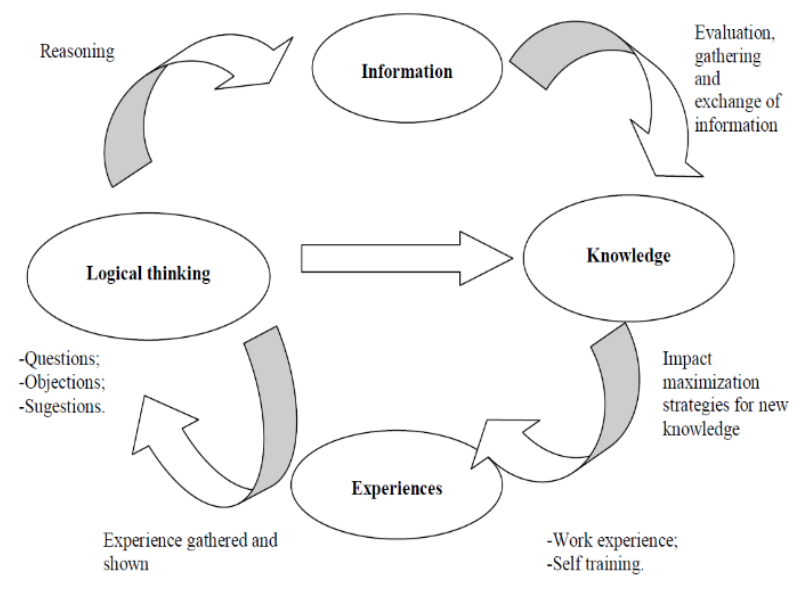

Fig. 3. Knowledge Circle

\section{CONSIDERATIONS REGARDING A CLUSTER BUILDING}

The main reasons leading to the need to establish clusters, obtained as a result of K-regional SWOT analyses are as follows[12]:

- integrated smart sustainable development, supporting of entrepreneurship and stabilization of employment;

- increasing employability of the workforce and reducing unemployment;

- changing psychology of communities on sustainable development and raising their environmental awareness;
- creating new disciplines of study and occupational standards for sustainable development and "green" labor market;

- improving communication between consumers, producers (especially on the issue of sustainable consumption and production), educational institutions, research centers and public authorities;

- increasing regional cohesion between rural communities;

- Increasing regional cohesion between companies belonging to certain areas of interest.

The main objectives of a regional cluster are: development of products and services specific to the cluster; developing a coherent cluster - brand policy; participation in national and international forums (conferences, fairs and exhibitions, economic events); participation in national and international projects; development of national and international economic relations; development of joint marketing within the cluster; monitoring financing programs, assist in drawing up financing of projects; collaborations/partnerships with organizations and clusters in the country and abroad; participation in meetings, brokerages between clusters; exchange of experience, best practices and transfer of knowledge between clusters in the country and abroad; development of digital economy in organizations belonging to the cluster; drafting legislative proposals; legislation awareness among members; professional development of managers and employees; fund raising for the implementation of sustainable development in the interest area of cluster management; harmonization and representation of the interests of all members; increasing the competitiveness of eco-bioeconomic sector in Romania (biomass, crop rotation etc.); creating conditions to ensure sustainable development of the regions in the geographical area of the cluster; establishing a common strategy for regional development; representing the interests of businesses and specific educational establishments in the region; support accession of new members in the cluster; collaboration with the local, regional and central authorities to ensure sustainable regional development; alert about the new opportunities on financing sources for projects of common interest; detection of new financing mechanisms necessary for a proper functioning of the cluster; creating an "integrated sustainable triangle" formed of a center for successful knowledge sharing, a center of excellence in entrepreneurship and a pilot center for cooperation in areas of regional interest[13]. Given the possible objectives of a cluster and the existing regional entities, can be 
"Mircea cel Batran" Naval Academy Scientific Bulletin, Volume XIX - 2016 - Issue 1

Published by "Mircea cel Batran" Naval Academy Press, Constanta, Romania /I The journal is indexed in:

PROQUEST / DOAJ / DRJI / JOURNAL INDEX I I2OR / SCIENCE LIBRARY INDEX / Google Scholar / Crossref I

Academic Keys / ROAD Open Access / OAJI / Academic Resources / Scientific Indexing Services / SCIPIO

determined a hypothetical structure, according to examples shown in Table 1.

Table 1 Members of regional cluster

\begin{tabular}{|c|c|}
\hline $\begin{array}{c}\text { Institutions/ } \\
\text { organizations }\end{array}$ & Activity items \\
\hline $\begin{array}{l}\text { Suppliers of } \\
\text { CVT } F_{1}, F_{2}, \ldots \\
F_{n .}\end{array}$ & Schools with specific domain \\
\hline $\begin{array}{l}\text { Organization } \\
\text { working in } \\
\text { several fields } \\
\mathrm{O}_{1}\end{array}$ & $\begin{array}{l}\text { Distribution and processing } \\
\text { steel products. Commerce of } \\
\text { petroleum products. Foreign } \\
\text { trade. Freight }\end{array}$ \\
\hline $\begin{array}{l}\text { Manufacturers } \\
\text { of furniture - } \\
\mathrm{M}_{1}, \mathrm{M}_{2}, \mathrm{M}_{\mathrm{n}}\end{array}$ & Production of furniture. \\
\hline $\begin{array}{l}\text { Manufactures } \\
\text { of cement }-\mathrm{C}_{1}\end{array}$ & $\begin{array}{llr}\begin{array}{l}\text { Production of cement and } \\
\text { ecologic } \\
\text { insulation }\end{array} & & \text { "Thermalan" } \\
\end{array}$ \\
\hline $\begin{array}{l}\text { Company } \\
\text { producing } \\
\text { bricks }-\mathrm{Z1}\end{array}$ & $\begin{array}{l}\text { Production of bricks (in the } \\
\text { future will be produced } \\
\text { ecological bricks) }\end{array}$ \\
\hline $\begin{array}{l}\text { Rearing farms } \\
A_{1}, A_{2}, . . A_{n}\end{array}$ & Poultry and harvesting biomass \\
\hline Bank B 1 & $\begin{array}{l}\text { Universal commercial bank } \\
\text { aimed mainly to finance SMEs, } \\
\text { agriculture, local public } \\
\text { administrations, as well as } \\
\text { those bankable projects which } \\
\text { by their nature contribute to } \\
\text { economic development, } \\
\text { creating and maintaining jobs. }\end{array}$ \\
\hline $\begin{array}{l}\text { Research } \\
\text { institutes }\end{array}$ & $\begin{array}{l}\text { Research in the field of } \\
\text { industrial engineering }\end{array}$ \\
\hline Foundation $\mathrm{E}_{1}$ & $\begin{array}{l}\text { Foundation for excellence } \\
\text { educational }\end{array}$ \\
\hline $\begin{array}{l}\text { Company } \\
\text { producing } \\
\text { plastics }-\mathrm{P}_{1}\end{array}$ & $\begin{array}{l}\text { Manufacturing various plastic } \\
\text { components }\end{array}$ \\
\hline $\begin{array}{l}\text { Inter-cultural } \\
\text { and interfaith } \\
\text { entity - } \mathrm{ICC}_{1}\end{array}$ & $\begin{array}{l}\text { Entity (governmental body) of } \\
\text { studies and spiritual holidays. }\end{array}$ \\
\hline \multirow[t]{4}{*}{ Others } & Small farmers \\
\hline & $\begin{array}{l}\text { Farms with / without the status } \\
\text { of SMEs }\end{array}$ \\
\hline & Agricultural associations \\
\hline & $\begin{array}{l}\text { Educational institutions (high } \\
\text { schools and school groups) }\end{array}$ \\
\hline University $U_{1}$ & $\begin{array}{l}\text { Activities in research and } \\
\text { innovation }\end{array}$ \\
\hline $\begin{array}{l}\text { County Office } \\
\text { of FAS; County } \\
\text { Chamber of } \\
\text { Commerce, } \\
\text { Industry and } \\
\text { Agriculture }\end{array}$ & $\begin{array}{l}\text { Catalysts for innovative } \\
\text { processes following a process } \\
\text { of generating eco-bio-economic } \\
\text { cluster (through a methodology) }\end{array}$ \\
\hline Local councils & Makes autonomy of localities \\
\hline
\end{tabular}

\begin{tabular}{|l|l|}
\hline \multicolumn{1}{|c|}{$\begin{array}{c}\text { Institutions/ } \\
\text { organizations }\end{array}$} & \multicolumn{1}{|c|}{ Activity items } \\
\hline $\begin{array}{l}\text { which belong to } \\
\text { common }\end{array}$ & they represent \\
\hline $\begin{array}{l}\text { Specialized } \\
\text { NGO }\end{array}$ & $\begin{array}{l}\text { Promoting Romanian original } \\
\text { scientific research }\end{array}$ \\
\hline $\begin{array}{l}\text { Association of } \\
\text { local investors; } \\
\text { Foundation for } \\
\text { sustainable } \\
\text { territories }\end{array}$ & $\begin{array}{l}\text { National and international } \\
\text { cooperation (partnership) in } \\
\text { areas of interest of the cluster }\end{array}$ \\
\hline $\begin{array}{l}\text { Other } \\
\text { interested }\end{array}$ & \\
entities & \\
\hline
\end{tabular}

Given the involvement of public administration in the process of sustainable development through regional clusters, we can analyses the interactions at the level of these entities, and at the level of an alliance/ regions. Interactions between knowledge and the role and degree of involvement of public administrations can be analyzed from more points of view. The first view is the one concerning the situation and the citizen's relations within the state, relations that should guarantee primarily public freedom as shown in Figure 4 [14].

Starting from the schema of the concept of public liberty, shown in Figure 4, can be determined the interactions between entities/characteristics of a regional cluster, knowledge gained and used in the process of sustainable development and that of the role/involvement of public administration management by ensuring public freedoms, as shown in Figure 5. The interdependence of the elements listed above, may be determined on the basis of the following elements:

- a cluster is a form of strategic partnership, based on freedom of association guaranteed in a democratic way;

- the cluster protects vulnerable SME in terms of intellectual property, as public liberty ensures the right to freedom of property;

- the cluster contains an inter-cultural and interfaith entity, based on freedom of religious belief and existence of a "mottled" society (due to immigration and emigration phenomena), focused on inter-culturalism (education towards openness to multiple values);

- individual and organizational learning is guaranteed by the right to quality education/training;

- knowledge sharing;

- social commerce, based on Facebook social network developed at global level due to free existence of mass communication channels;

- thinking (synonymous with "Judgement"), based on information and an operational 
"Mircea cel Batran" Naval Academy Scientific Bulletin, Volume XIX - 2016 - Issue 1

Published by "Mircea cel Batran" Naval Academy Press, Constanta, Romania /I The journal is indexed in:

PROQUEST / DOAJ / DRJI / JOURNAL INDEX I I2OR / SCIENCE LIBRARY INDEX / Google Scholar / Crossref I

Academic Keys / ROAD Open Access / OAJI / Academic Resources / Scientific Indexing Services / SCIPIO

component, is a superior cognitive psychological process of reflection of reality in the abstract form of notions, judgements and reasoning;

- $\quad$ concepts are products of reasoning [15].

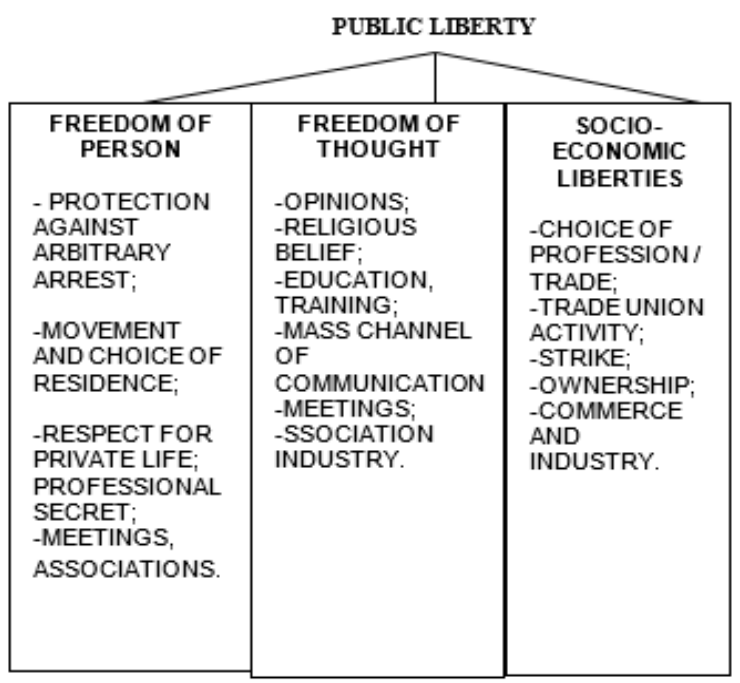

Fig. 4. Scheme of public freedom concept scheme

In this paper we proceeded to obtain and transfer knowledge through a procedure built and implemented on the basis of a number of two forms: Knowledge Transfer Knowledge Transfer Form 1 and respectively Form 2 .

Form for calculating the number of pieces of knowledge created and shared at organizational level - code TKF1 (Transfer Knowledge Form 1).

This procedure describes the processes of accumulation and efficient transfer of knowledge between cluster members and partners, using methods/techniques/strategies that are coordinated through a center for successful knowledge transfer. The procedure applies both to the transfer of knowledge and to all entities with responsibilities in the area of knowledge management.

Given the need for mathematical calculations (number of participants, duration and efficiency of operations, etc.), we used in this purpose an Excel spreadsheet. Similar to Gantt diagrams type, each activity was split into subtasks (SA1, SA2 etc.) in order to introduce specific records. Analysis of knowledge generating activities can lead to the obtaining and sharing of new knowledge by following these two steps: The first step consists in the establishment of a minimal number of five actions $\left(A_{1} \ldots A_{5}\right)$ which led to the obtaining of new knowledge in a certain area (industrial, tourism, education and others); Step two consists in creation of five tables, one for each action, for which the After Action Review

DOI: $10.21279 / 1454-864 X-16-11-080$

(c) 2015. This work is licensed under the Creative Commons Attribution-Noncommercial-Share Alike 4.0 License.
(AAR) method, developed by the US Armed Forces, will be implemented as can be seen in Table 2[16].

Table 2. Implementation of the AAR method for activity $\mathrm{A} 1$

\begin{tabular}{|c|c|c|}
\hline $\begin{array}{l}\text { Question/ } \\
\text { Answer }\end{array}$ & $\begin{array}{l}\text { What should } \\
\text { have } \\
\text { happened? } \\
\text { Why? }\end{array}$ & $\begin{array}{l}\text { Suggestions } \\
\text { I Conclusions }\end{array}$ \\
\hline $1 \ldots 4$ & & $\begin{array}{ll}\text { SC1.1 } & \ldots \\
\text { SC1.4 }\end{array}$ \\
\hline $\begin{array}{l}\text { Question } \\
\text { Answer }\end{array}$ & $\begin{array}{l}\text { What actually } \\
\text { happened? } \\
\text { Why? }\end{array}$ & $\begin{array}{l}\text { Suggestions / } \\
\text { Conclusions }\end{array}$ \\
\hline $1 \ldots 4$ & & $\begin{array}{l}\text { SC2.1... } \\
\text { SC2.4 }\end{array}$ \\
\hline $\begin{array}{l}\text { Question } \\
\text { Answer }\end{array}$ & $\begin{array}{l}\text { What is the } \\
\text { difference? } \\
\text { Why? }\end{array}$ & $\begin{array}{l}\text { Suggestions / } \\
\text { Conclusions }\end{array}$ \\
\hline $\begin{array}{ll}\text { Between } & \text { A1 } \\
\text { and A2 } & \ldots \\
\text { between } & \text { A1 } \\
\text { and A5 } & \\
\end{array}$ & & $\begin{array}{l}\text { SC3.1... } \\
\text { SC3.4 }\end{array}$ \\
\hline $\begin{array}{l}\text { Question } \\
\text { Answer }\end{array}$ & $\begin{array}{l}\text { What went } \\
\text { wrong? Why? }\end{array}$ & $\begin{array}{l}\text { Suggestions / } \\
\text { Conclusions }\end{array}$ \\
\hline $1 \ldots 4$ & & $\begin{array}{l}\text { SC4.1... } \\
\text { SC4.4 }\end{array}$ \\
\hline $\begin{array}{l}\text { Question } \\
\text { Answer }\end{array}$ & $\begin{array}{ll}\text { What } & \text { could } \\
\text { have } & \text { gone } \\
\text { better? } & \\
\text { Why? } & \\
\end{array}$ & $\begin{array}{l}\text { Suggestions / } \\
\text { Conclusions }\end{array}$ \\
\hline $1 \ldots 4$ & & $\begin{array}{l}\text { SC5.1... } \\
\text { SC5.4 }\end{array}$ \\
\hline $\begin{array}{l}\text { Question } \\
\text { Answer }\end{array}$ & $\begin{array}{l}\text { What lessons } \\
\text { can we learn? }\end{array}$ & $\begin{array}{l}\text { Suggestions / } \\
\text { Conclusions }\end{array}$ \\
\hline $1 \ldots 4$ & & $\begin{array}{l}\text { SC6.1... } \\
\text { SC6.4 }\end{array}$ \\
\hline
\end{tabular}

The number of knowledge created and shared $\left(\mathrm{K}_{\mathrm{CT}}\right)$ at a certain time by an organization can be calculated using the following formula 1 :

$K_{C T}=6 * N_{A} * N_{S} * N_{I}=6 * 4 * 24 * 30=17280$ [knowledge]

Where:

$6=$ number of questions used with the AAR method;

$\mathrm{N}_{\mathrm{A}}=$ number of analyzed sub activities (in this case 4);

$\mathrm{N}_{\mathrm{s}}=$ number of suggestions / conclusions / results (in this case - 24);

$\mathrm{N}_{\mathrm{I}}=$ number of participants (in this case - 30). 
"Mircea cel Batran" Naval Academy Scientific Bulletin, Volume XIX - 2016 - Issue 1

Published by "Mircea cel Batran" Naval Academy Press, Constanta, Romania /I The journal is indexed in:

PROQUEST / DOAJ / DRJI / JOURNAL INDEX I I2OR / SCIENCE LIBRARY INDEX / Google Scholar / Crossref I

Academic Keys / ROAD Open Access / OAJI / Academic Resources / Scientific Indexing Services / SCIPIO

\begin{tabular}{|l|l|}
\hline \multicolumn{1}{|c|}{ ClUSTER } & \multicolumn{1}{c|}{ KNOWLEDGE } \\
-STRATEGIC ASSOCIATION; & -ABLITIES; \\
-NTELECTUAL PROPERTY; & -EXPERIENCE; \\
-INTERCULTURALITY; & -NFORMATION; \\
-KNOWLEDGE WORKERS \& & -INTUITION; \\
KBO; & -STORAGE MEDIA; \\
-PUBLIC ADMINISTRATION; & -PERCEPTION; \\
-CATALYSTS; -PARTNERS; & -ORGANISATIONAL \\
-REGIONAL & NORMS; \\
DEVELOPMENT; & -KNOWLEDGE \\
-KNOWLEDGE SHARING; & MANAGEMENT. \\
\hline \multicolumn{1}{|c|}{ PUBLIC LIBERTY } & \\
-ASSOCIATION; & -PROPERTY; \\
-CHANNELS OF MASS & -RELIGIOUS BELIEF \\
COMMUNICATION; & -EDUCATION/TRAINING \\
-TRADE \& INDUSTRY; & \\
\hline
\end{tabular}

Fig. 5. The interdependence between knowledge clusters and the role of public freedom

Processing and efficiency form for idea results using the SMART method - code TKF2 (Transfer Knowledge Form 2)

Considering the quality evaluation of proposed ideas by the employees of an organization the six questions proposed by the SMART method can be used, as shown in Table 3[17].

In order to register the knowledge resulted from the processing of an idea we also need to answer the following questions: How many areas are there $\left(\mathrm{N}_{\mathrm{D}}\right)$ with theoretical /practical implementation opportunities for the respective idea? How many new ideas $\left(\mathrm{N}_{1}\right)$ were generated from the evaluation of the initial idea? How many new questions $\left(\mathrm{N}_{\mathrm{Q}}\right.$ - which will require answers and generate new knowledge) resulted from the processing of the initial idea? What is the applicability rating $\left(R_{A}\right.$ - explained in Table 4$)$ for the idea's results depending on the geographic dispersion of the users/beneficiaries?
Table 3. Idea processing using the SMART method

\begin{tabular}{|c|c|c|}
\hline $\begin{array}{l}\text { Question } \\
\text { I Answer }\end{array}$ & $\begin{array}{l}\text { Where does } \\
\text { this idea } \\
\text { come from? }\end{array}$ & $\begin{array}{l}\text { Suggestions } \\
\text { Conclusions }\end{array}$ \\
\hline $1 \ldots 4$ & & SC1.1 ... SC1.4 \\
\hline $\begin{array}{l}\text { Question } \\
\text { I Answer }\end{array}$ & $\begin{array}{l}\text { When did it } \\
\text { appear? }\end{array}$ & $\begin{array}{l}\text { Suggestions } \\
\text { Conclusions }\end{array}$ \\
\hline $1 \ldots 4$ & & SC2.1 .. SC2.4 \\
\hline $\begin{array}{l}\text { Question } \\
\text { / Answer }\end{array}$ & $\begin{array}{l}\text { What were the } \\
\text { conditions } \\
\text { which lead to } \\
\text { its } \\
\text { appearance? }\end{array}$ & $\begin{array}{l}\text { Suggestions } \\
\text { Conclusions }\end{array}$ \\
\hline $\begin{array}{l}\text { Between } \\
\text { A1 and } \\
\text { A2 ... } \\
\text { Between } \\
\text { A1 and } \\
\text { A5 }\end{array}$ & & SC3.1 ... SC3.4 \\
\hline $\begin{array}{l}\text { Question } \\
\text { / Answer }\end{array}$ & $\begin{array}{l}\text { Which are the } \\
\text { factors that } \\
\text { lead to its } \\
\text { development? }\end{array}$ & $\begin{array}{l}\text { Suggestions } \\
\text { Conclusions }\end{array}$ \\
\hline $1 \ldots 4$ & & SC4.1 ... SC4.4 \\
\hline $\begin{array}{l}\text { Question } \\
\text { / Answer }\end{array}$ & $\begin{array}{l}\text { How should it } \\
\text { be properly } \\
\text { capitalized? }\end{array}$ & $\begin{array}{l}\text { Suggestions } \\
\text { Conclusions }\end{array}$ \\
\hline $1 \ldots 4$ & & SC5.1... SC5.4 \\
\hline $\begin{array}{l}\text { Question } \\
\text { / Answer }\end{array}$ & $\begin{array}{l}\text { Why is it } \\
\text { relevant at } \\
\text { this stage? }\end{array}$ & $\begin{array}{l}\text { Suggestions } \\
\text { Conclusions }\end{array}$ \\
\hline $1 \ldots 4$ & & SC6.1 ... SC6.4 \\
\hline
\end{tabular}

In this situation the number of knowledge gathered and shared from the processing of an idea $\left(\mathrm{K}_{\mathrm{I}}\right)$ can be calculated using relation 2 .

$K_{I}=R_{A} / 6 *\left(N_{S}+N_{D}+N_{I}+N_{Q}\right)$

Where:

$\mathrm{R}_{\mathrm{A}}=$ Applicability rating;

$6=$ Number of questions used by the SMART method;

$\mathrm{N}_{\mathrm{s}}=$ Number of suggestions generated by answers given to questions from the SMART method;

$N_{D}=$ Number of areas benefiting from the idea's implementation;

$N_{1}=$ Number of new ideas generated;

$\mathrm{N}_{\mathrm{Q}}=$ Number of new generated questions. 


\begin{abstract}
"Mircea cel Batran" Naval Academy Scientific Bulletin, Volume XIX - 2016 - Issue 1 Published by "Mircea cel Batran" Naval Academy Press, Constanta, Romania /I The journal is indexed in: PROQUEST / DOAJ / DRJI / JOURNAL INDEX I I2OR / SCIENCE LIBRARY INDEX / Google Scholar / Crossref I Academic Keys / ROAD Open Access / OAJI / Academic Resources / Scientific Indexing Services / SCIPIO
\end{abstract}

Table 4. Applicability rating for an idea's results

\begin{tabular}{|l|l|l|}
\hline $\begin{array}{l}\text { Level of } \\
\text { geographic } \\
\text { dispersion }\end{array}$ & Rating & Applicability \\
\hline Local & 1 & Low \\
\hline Regional & 2 & Extended \\
\hline
\end{tabular}

\begin{tabular}{|l|l|l|}
\hline $\begin{array}{l}\text { Level of } \\
\text { geographic } \\
\text { dispersion }\end{array}$ & Rating & Applicability \\
\hline National & 3 & Large scale \\
\hline International & 4 & Very large scale \\
\hline
\end{tabular}

\title{
CONCLUSIONS
}

After studies (based on a hypothetical cluster), we determined that the connecting elements between the knowledge, conscience and simulation-modelling techniques are experience, information and thinking. In the same context, we analysed the interdependence between knowledge, strategic alliances and public freedoms, establishing that it is based on the following elements: managerial relationships based on knowledge [23-24], channels of mass communication, thinking, learning, inter-culturality and associations of entities with common interests at regional level. System procedure, by forms TKF1 and TKF2 allowed to establish calculation formulas of knowledge created and shared at a cluster level. Regarding the options for the use of databases at a cluster level, SQL version remains the first solution, given the large number of suppliers, tutorials and adjacent existing supports. NoSQL systems requirements are further amplified, especially due to horizontal scalability, which remains constant regardless of the volume of processed data. Possibilities of transfer of knowledge gained by intellectual capital must be secured through two main methods: the use of efficient databases and increase the number of effective open-source programs (especially due to the need of costs reduction). The beneficiaries of these services are the ones who must choose between consistency and performance.

\section{BIBLIOGRAPHY}

[1] Oprean, C. Tîțu, M.A. Quality management and organization knowledge-based economy. AGIR PH, Bucharest, 2008;

[2] Pîrnău, C. Contributions On Integration Of Knowledge Management In The Sustainable Development Of Small And Medium - Sized Enterprises, Ph D Thesis, Lucian Blaga University of Sibiu, March 2015;

[3] Schreiber, C. Carley, K. The Impact of Databases on Knowledge Transfer: Simulation Providing Theory, Institute for Software Research, International Center for the Computational Analysis of Social and Organizational Systems, Carnegie Mellon University, Pittsburgh, Pennsylvania, USA, 2003.

[4] https://www.mongodb.com/nosql-explained;

[5] Căruțașu, N.L. Căruțașu, G. Cloud ERP implementation, FAIMA Business \& Management Journal, Vol.4 Issue 1/2016, pp. 31-43, 2016, ISSN 2344-4088

[6] Rahm, E. Endrullis, S. Charakteristika und Vergleich von SQL- und NoSQL Datenbanken, Universität Leipzig, Fakultät für Mathematik und Informatik, Deutschland, 2011;

[7] Küspert, K. Göbel, A. NoSQL Datenbanken, Friedrich-Schiller Universität Jena, Fakultät für Mathematik und Informatik, Deutschland, 2010;

[8] Ëbner, W. NoSQL Datenbanken, Institut für Informationswirtschaft, Wirtschaftsuniversität, Wien, Österreich, 2014;

[9] Ey, H. Consciousness. Scientific and Encyclopedic PH, Bucharest, 1983;

[10] Anghelache, C. Elements of modelling business processes. Course notes. Artifex PH, Bucharest, 2006;

[11]Țittu, M.A. Pîrnău, C. Pîrnău, M. Creativity, Education and Quality for Sustainable Development, the real Support for the Innovative Cluster's European Network, 8th Research/Expert Conference with International Participations, „QUALITY 2013”, Neum, Bosnia \& Herzegovina, June 2013, pp. 19-24, ISSN 1512-9268;

[12] Kempf, K.G. Keskinocak, P. Uzsoy, R. Planning Production and Inventories in the Extended Enterprise, Springer International Publisher, 2011;

[13] Costake, N. Public Administration Management, Strategic Management PH, Bucharest 1994;

[14] Popescu-Neveanu, P. General psychology course, Bucharest University, 1976;

[15] ${ }^{\star \star \star}$ The After Action Review, Mission-Centered Solutions Inc., Colorado, USA, 2008;

[16] Ayers, J. Programs. Service-Learning, Maryland State Department of Education, USA, 2003;

[17] Botezatu, C. Căruțașu, G. Strategies on Software Integration, Journal of Information Systems \& Operations Management, 2008;

[18] Pîrnău, M. Implementing Web Services Using Java Technology, International Journal of Computers, Communications and Control, 5(2), pp 251-260, 2010;

[19] Pîrnău, M. Pîrnău, C. e.g. The SOAP Protocol Used for Building and Testing Web Services, Proceedings of the World Congress on Engineering 2011, Vol. 1, ISBN 978-988-18210-6-5. pp. 475-480, London, UK;

[20]Adele, H. Stamp Student Union Technology Services, Defining Service Learning and Its Importance, University of Maryland, USA, 2014; 
"Mircea cel Batran" Naval Academy Scientific Bulletin, Volume XIX - 2016 - Issue 1 Published by "Mircea cel Batran" Naval Academy Press, Constanta, Romania /I The journal is indexed in: PROQUEST / DOAJ / DRJI / JOURNAL INDEX / I2OR / SCIENCE LIBRARY INDEX / Google Scholar / Crossref / Academic Keys / ROAD Open Access / OAJI / Academic Resources / Scientific Indexing Services / SCIPIO

[21] Popescu, M. Ionescu, V. Building and Using Web Services in Microsoft Technology, International Conference "Education and Creativity for a Knowledge Based Society", Section III- Computer Science, Titu Maiorescu University, 9th Edition, 19th-20th November 2015, Bucharest;

[22] lacob (Ciobanu), N.M. Fragmentation and Data Allocation in the Distributed Environments, Annals of the University of Craiova, Mathematics and Computer Science Series, Vol. 38, Nr. 3, 2011, pp. 76-83;

[23] Ciobanu (lacob), N.M. Algorithm for Dynamic Partitioning and Reallocation of Fragments in a Distributed Database, International Journal of Computer Science Research and Application - IJCSRA, Vol. 03, Issue 01 (Special Issue), 2013, pp. 39-47;

[24] Călmus, C.S. Răcuciu, C. Message Encryption in Office 365, International Conference "Education and Creativity for a Knowledge Based Society", Section III- Computer Science, Titu Maiorescu University, 9th Edition, 19th-20th November 2015, Bucharest. 